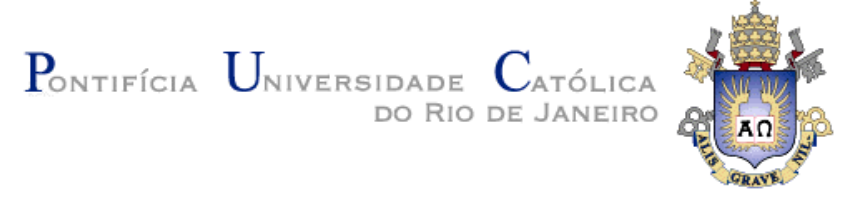

Pedro Henrique Ribeiro de Assis

\begin{abstract}
Distant Supervision for Relation Extraction using Ontology Class Hierarchy-Based Features
\end{abstract}

Dissertation presented to the Programa de Pós-Graduação em Informática of the Departamento de Informática, PUC-Rio as partial fulfillment of the requirements for the degree of Mestre em Informática

Advisor: Prof. Marco Antonio Casanova

Rio de Janeiro

March 2014 
Pedro Henrique Ribeiro de Assis

\section{Distant Supervision for Relation Extraction using Ontology Class Hierarchy-Based Features}

Dissertation presented to the Programa de Pós-Graduação em Informática, of the Departamento de Informática do Centro Técnico Científico da PUC-Rio, as partial fulfillment of the requirements for the degree of Mestre.

Prof. Marco Antonio Casanova

Advisor

Departamento de Informática - PUC-Rio

Prof. Alberto Henrique Frade Laender Departamento de Ciência da Computação - UFMG

Prof. Ruy Luiz Milidiú

Departamento de Informática - PUC-Rio

Prof. José Eugenio Leal

Coordinator of the Centro Técnico Científico da PUC-Rio

Rio de Janeiro, March 20th, 2014 


\section{All rights reserved}

\section{Pedro Henrique Ribeiro de Assis}

Graduated in Computer Science from Universidade Federal de Minas Gerais (UFMG), Minas Gerais - Brazil in 2011. He joined the Master in Informatics at Pontifical Catholic University of Rio de Janeiro (PUCRio) in 2012.

Bibliographic data

Ribeiro de Assis, Pedro Henrique

Distant Supervision for Relation Extraction using Ontology Class Hierarchy-Based Features / Pedro Henrique Ribeiro de Assis; advisor: Marco Antonio Casanova. - 2014.

$64 \mathrm{f}$ : : il. (color) ; $30 \mathrm{~cm}$

Dissertação (Mestrado em Informática)-Pontifícia Universidade Católica do Rio de Janeiro, Rio de Janeiro, 2014.

Inclui bibliografia

1. Informática - Teses. 2. Extração de relações. 3. Web semântica. 4. Processamento natural de linguagens. 5. Aprendizado de máquina. 6. Supervisão a distância. I. Casanova, Marco Antonio. II. Pontifícia Universidade Católica do Rio de Janeiro. Departamento de Informática. III. Título.

CDD: 004 


\section{Acknowledgments}

I would like to thank one of the best advisors I have ever had, professor Marco Antonio Casanova. His support, wisdom, experience and patience were always a source of motivation for me and were essential for this work.

To Prof. Ruy Milidiú for his support, attention and help with mathematical models applied in this work.

To PUC-Rio for funding my research and for giving me the opportunity to be a student of the Department of Informatics which is a fantastic and remarkable academic community.

To my parents for unconditional love.

And to my friends for always helping me to stay motivated and focused, except, of course, on sunny weekends. 


\section{Abstract}

Assis, Pedro; Casanova, Marco Antonio (Advisor). Distant Supervision for Relation Extraction using Ontology Class Hierarchy-Based Features. Rio de Janeiro, 2014. 64p. MSc. Dissertation - Departamento de Informática, Pontifícia Universidade Católica do Rio de Janeiro.

Relation extraction is a key step for the problem of rendering a structure from natural language text format. In general, structures are composed by entities and relationships among them. The most successful approaches on relation extraction apply supervised machine learning on hand-labeled corpus for creating highly accurate classifiers. Although good robustness is achieved, hand-labeled corpus are not scalable due to the expensive cost of its creation. In this work we apply an alternative paradigm for creating a considerable number of examples of instances for classification. Such method is called distant supervision. Along with this alternative approach we adopt Semantic Web ontologies to propose and use new features for training classifiers. Those features are based on the structure and semantics described by ontologies where Semantic Web resources are defined. The use of such features has a great impact on the precision and recall of our final classifiers. In this work, we apply our theory on corpus extracted from Wikipedia. We achieve a high precision and recall for a considerable number of relations.

\section{Keywords}

Relation Extraction, Distant Supervision, Semantic Web, Machine Learning, Natural Language Processing 


\section{Resumo}

Assis, Pedro; Casanova, Marco Antonio. Supervisão à distância em extração de relacionamentos usando características baseadas em hierarquia de classes em ontologias. Rio de Janeiro, 2014. 64p. Dissertação de Mestrado - Departamento de Informática, Pontifícia Universidade Católica do Rio de Janeiro.

Extração de relacionamentos é uma etapa chave para o problema de identificação de uma estrutura em um texto em formato de linguagem natural. Em geral, estruturas são compostas por entidades e relacionamentos entre elas. As propostas de solução com maior sucesso aplicam aprendizado de máquina supervisionado a corpus anotados à mão para a criação de classificadores de alta precisão. Embora alcancem boa robustez, corpus criados à mão não são escaláveis por serem uma alternativa de grande custo. Neste trabalho, nós aplicamos um paradigma alternativo para a criação de um número considerável de exemplos de instâncias para classificação. Tal método é chamado de supervisão à distância. Em conjunto com essa alternativa, usamos ontologias da Web semântica para propor e usar novas características para treinar classificadores. Elas são baseadas na estrutura e semântica descrita por ontologias onde recursos da Web semântica são definidos. $\mathrm{O}$ uso de tais características tiveram grande impacto na precisão e recall dos nossos classificadores finais. Neste trabalho, aplicamos nossa teoria em um corpus extraído da Wikipedia. Alcançamos uma alta precisão e recall para um número considerável de relacionamentos.

\section{Palavras-chave}

Extração de Relacionamentos, Supervisão à Distância, Web Semântica, Aprendizado de Máquina, Processamento Natural de Linguagens 


\section{Table of Contents}

1 Introduction 11

1.1 Motivation 11

1.2 Goals and Contributions 12

1.3 Related Work 12

1.4 Dissertation Structure 14

2 Background 15

$\begin{array}{ll}\text { 2.1 The Semantic Web } & 15\end{array}$

2.1.1 An Architecture for the Semantic Web 15

$\begin{array}{ll}\text { 2.1.2 The Coding Layer } & 17\end{array}$

$\begin{array}{ll}\text { 2.1.3 The Structure Layer } & 18\end{array}$

2.1.3.1 XML + XML Schema + XML Namespaces 18

2.1.3.2 RDF + RDF Schema 23

2.1.4 The Inference Layer 26

2.1.4.1 Ontology Description Languages 26

2.1.4.2 Rule Inference $\quad 29$

2.1.5 The Linked Data Principles 31

2.1.6 The Linked Open Data Project 32

2.2 Natural Language Processing 33

2.2.1 Sentence Boundary Disambiguation 33

2.2.2 Part-of-Speech Tagging 35

$\begin{array}{ll}2.3 \text { Classification Methods } & 37\end{array}$

$\begin{array}{ll}2.3 .1 \text { Overview } & 37\end{array}$

2.3.2 Logistic Regression 38 
2.3.3. Multi-class Perceptron $\quad 40$

$\begin{array}{ll}2.4 \text { Summary } & 42\end{array}$

3 The Relation Extraction Problem 42

3.1 Approach $\quad 42$

3.2 Extraction Task Definition 43

3.3 Features $\quad 44$

3.3.1 Natural Language Processing Based Features 44

3.3.2 Ontology Class Hierarchy Based Feature 46

$\begin{array}{ll}3.4 \text { Summary } & 48\end{array}$

4 Experiments $\quad 49$

$\begin{array}{ll}4.1 \text { Corpus } & 50\end{array}$

4.2 Experimental Setup 52

4.3 Held-out Evaluation $\quad 54$

4.4 Human Evaluation $\quad 57$

4.5 Summary $\quad 59$

5 Conclusion 60

$\begin{array}{ll}5.1 \text { Contributions } & 60\end{array}$

5.2 Limitations and Future Work 60

6 Bibliography $\quad 62$ 


\section{List of Figures}

Figure 1: The three architectural bases of the Web 16

Figure 2: An example of the referencing mechanism using URI 17

Figure 3: An example of XML for representing books 18

Figure 4: Two stretches of XML files. At the top an HTML table and at the bottom values about a table (furniture) 19

Figure 5: Use of namespaces in an XML document with name conflicts 20

Figure 6: Example of an XML document representing a shipping order

Figure 7: Example of an XML Schema that is valid for the $\mathrm{XML}$ Document in Figure 6

Figure 8: Example of an RDF resource in N3 format 23

Figure 9: Example of an RDF resource in RDF/XML format 23

Figure 10: The graph model described in the RDF examples of Figure 8 and 9

Figure 11: Example of the use of constructs of RDF Schema to define a class hierarchy 25

Figure 12: An example of taxonomy of the kingdoms of life 26

Figure 13: An example of OWL file describing an transport ontology 29 Figure 14: The LOD Cloud Diagram at September 2011 Figure 15: An example of sigmoid function 37

Figure 16: A class hierarchy sub-tree from DBpedia 45

Figure 17: A class hierarchy sub-tree from DBpedia with cut $h=2 \quad 46$

Figure 18: Histogram for the number of occurrences for each relation 


\section{List of Tables}

Table 1: Lexical features and examples

Table 2: Features of $s$ based on Ontology Class Based Hierarchy

Features $\quad 45$

Table 3: Top 20 relations in number of examples in the dataset 51

Table 4: Relations for a classifier trained with lexical features only 52

Table 5: Top 20 relations for a classifier trained with semantic features only

Table 6: Top 20 relations for a classifier trained with lexical and semantic features

Table 7: Number of classes with at least $70 \%$ of F-measure by set of features

Table 8: Average accuracy for the top 10 relations in examples in our dataset for human evaluation of a sample of 100 predictions 